\title{
Biofouling dan Korosi pada Infrastruktur Energi Laut di Indonesia: Analisis Bibliometrik
}

\author{
Agung Iswadi ${ }^{*}$, Gadang Priyotomo ${ }^{2}$ \\ ${ }^{1}$ Program Studi Teknik Mesin, Fakultas Teknik dan Sains, Universitas Nasional, Jalan Sawo \\ Manila, Pejaten, Pasar Minggu, Jakarta Selatan 12520 \\ ${ }^{2}$ Pusat Penelitian Metalurgi dan Material, Lembaga Ilmu Pengetahuan Indonesia (LIPI), Kawasan \\ PUSPIPTEK, Gedung 470, Tangerang Selatan, Banten 15314 \\ *Korespondensi penulis: a.iswadi@civitas.unas.ac.id
}

(Received: 06-10-2020; Revised: 08-10-2020; Accepted: 19-10-2020)

\begin{abstract}
The target of reducing greenhouse gas emission has been followed by a number of actions across sectors, including renewable energy utilisation which provides a clean energy source. From various types of renewable energy resources, marine renewable energy has practical potential up to more than $17 \mathrm{GW}$, however, there is no installed energy generating capacity in Indonesia until today. Among technical challenges that have not been studied in the marine renewable energy sector in Indonesia is material robustness in coping with marine waters environment, i.e., biofouling and corrosion. This study will analyse the state of the knowledge of research topics: (i) marine renewable energy in Indonesia, and (ii) biofouling and corrosion in tropical waters of Indonesia to identify a research gap and discover a novel research topic for further investigation. By using bibliometric analysis, it is found that the impact of biofouling and corrosion on marine renewable energy infrastructure has not been widely investigated up to now. Thus, this research topic needs to be studied comprehensively in the near future.
\end{abstract}

Keywords: biofouling, corrosion, marine renewable energy, bibliometric analysis.

\begin{abstract}
Abstrak. Target penurunan emisi gas rumah kaca telah diikuti dengan sejumlah aksi di seluruh sektor, diantaranya dengan pemanfaatan energi terbarukan yang menyediakan sumber energi bersih. Dari berbagai jenis sumber energi terbarukan, energi laut memiliki potensi praktis hingga lebih dari $17 \mathrm{GW}$, namun hingga saat ini belum ada sama sekali kapasitas pembangkit energi yang terpasang di Indonesia. Diantara tantangan teknis yang belum dikaji secara mendalam di sektor energi laut Indonesia adalah ketahanan material terhadap lingkungan perairan laut, yaitu biofouling dan korosi. Studi ini akan menganalisis perkembangan pengetahuan dari topik penelitian: (i) energi laut di Indonesia dan (ii) biofouling dan korosi di perairan tropis Indonesia untuk mengidentifikasi research gap dan menemukan topik kajian yang memiliki tingkat kebaruan untuk dikaji lebih lanjut. Melalui analisis bibliometrik, diketahui bahwa kajian dampak biofouling dan korosi terhadap infrastruktur energi laut Indonesia masih belum banyak dikaji hingga saat ini. Sehingga, topik kajian ini perlu ditindaklanjuti dengan lebih komprehensif dalam waktu dekat.
\end{abstract}

Kata Kunci: biofouling, korosi, energi laut, analisis bibliometrik

\section{PENDAHULUAN}

Energi terbarukan telah dijadikan salah satu prioritas dalam menghadapi perubahan iklim dan pemanasan global dalam beberapa dekade terakhir. Di Indonesia, porsi pemanfaatan energi terbarukan meningkat cukup signifikan dengan adanya Kebijakan Energi Nasional yang tertuang dalam Peraturan Pemerintah No. 79 Tahun 2014. Capaian prosentase pemanfaatan energi terbarukan di dalam bauran energi nasional (national energy mix) ditargetkan sebesar $23 \%$ pada 2025 dan $31 \%$ pada 2050 [1]. Selain itu, pemanfaatan energi terbarukan juga sejalan dengan Sustainable Development Goal 7 (Sustainable and 
Affordable Clean Energy), mengingat salah satu penyuplai prosentase terbesar emisi gas rumah kaca (greenhouse gas) berasal dari fossil fuel energy [2].

Energi terbarukan dari laut merupakan salah satu energi terbarukan yang menjanjikan untuk mendukung penyediaan energi bersih dan penurunan emisi gas rumah kaca. Berdasarkan perhitungan potensi praktis (practical potential), Indonesia memiliki potensi energi arus laut sebesar 17.989 MW dan potensi energi gelombang laut sebesar 1.995 MW [3]. Kementerian Energi dan Sumber Daya Mineral (ESDM) menargetkan pengembangan energi laut pada 2021 mencapai sekitar 7 MW untuk memenuhi target capaian 23\% energi terbarukan di tahun 2025 [4]. Namun demikian, perkembangan energi laut di Indonesia saat ini masih dalam tahapan riset dan pengembangan prototipe teknologi yang disebabkan oleh beberapa faktor kendala dari kebijakan hingga batasan finansial. Kebijakan technology-push and market-pull perlu dijalankan secara seimbang untuk mempercepat pengembangan energi terbarukan di Indonesia, dimana disatu sisi terus mendorong pengembangan teknologi, dan disisi lain memberikan insentif kepada pasar untuk menyalurkan dana bagi pengembangan inovasi kearah komersial $[5,6]$.

Salah satu tantangan teknis dalam pengembangan teknologi energi laut adalah ketahanan jenis material (material robustness) yang digunakan dalam komponen perangkat terhadap lingkungan perairan laut. Diantara dampak lingkungan perairan laut terhadap infrastruktur teknologi energi laut adalah biofouling dan korosi [7-9]. Biofouling merupakan akumulasi mikroorganisme dan makroorganisme yang menempel pada permukaan bahan/material yang terendam di dalam laut yang dapat menyebabkan kerusakan struktural. Meskipun korosi pada umumnya dapat terjadi tanpa adanya media organisme laut, namun fenomena biofouling juga mampu memicu terjadi korosi yang dikenal dengan biocorrosion [10,11]. Topik biofouling dan korosi telah banyak dibahas oleh banyak peneliti, namun topik yang mengkaji dampak biofouling dan korosi terhadap ketahanan material infrastruktur energi laut di Indonesia masih sangat terbatas. Kajian ini akan membahas tentang review studi biofouling dan korosi, khususnya di perairan tropis Indonesia untuk melihat peluang penelitian di masa depan yang dapat berkontribusi pada percepatan pengembangan industri energi laut Indonesia.

\section{METODOLOGI}

Kajian ini dikerjakan dengan menggunakan analisis bibliometrik dari artikel yang telah diterbitkan di jurnal internasional dari tahun 2000 hingga 2020. Sumber metadata yang digunakan dalam analisis bibliometrik ini berasal dari website Scopus (https://www.scopus.com/). Tools yang digunakan dalam analisis bibliometrik ini adalah software VOSviewer (https://www.vosviewer.com/) dengan memvisualisasikan korelasi dari berbagai kata kunci (keywords) yang digunakan oleh para author dalam artikel jurnal. Analisis bibliometrik pada kajian ini meliputi 2 topik penelitian yang berbeda, yaitu (i) energi laut di Indonesia, dan (ii) biofouling dan korosi di perairan laut Indonesia. Untuk dapat menganalisis peluang penelitian di masa depan, korelasi dari kedua topik tersebut akan didiskusikan. Perbandingan kajian sejenis di bidang yang sama juga akan diulas melalui beberapa artikel internasional yang mengkaji dampak biofouling dan korosi pada infrastruktur energi laut di dunia.

\section{HASIL DAN PEMBAHASAN}

\section{Visualisasi Peta Topik 1: Penelitian Energi Laut di Indonesia}

Melalui ekstraksi data bibliografik artikel di website Scopus dengan topik penelitian energi laut dari tahun 2000 hingga 2020 diperoleh sebanyak 90 artikel yang terdiri dari 47 journal paper, 37 conference paper, 4 conference review paper, dan 2 review paper. Peta topik penelitian energi laut di Indonesia dibuat dengan menganalisis author keywords co- 
occurrence dan index keywords co-occurrence. Gambar 1, Gambar 2, dan Gambar 3 di bawah ini masing-masing memvisualisasikan pemetaan bibliografik dengan topik energi laut di Indonesia menggunakan network visualization, overlay visualization, dan density visualization.

Network visualization pada gambar 1 menunjukkan klaster dari masing-masing bahan kajian di bidang energi laut Indonesia. Sebagai contoh, "wave energy", "wave energy conversion", "water waves", dan "wave power" adalah beberapa kata kunci yang berada pada klaster berwarna merah, yang menunjukkan korelasi atau kedekatan hubungan dari kata kunci-kata kunci tersebut. Demikian juga kata kunci "Pacific Ocean", "tides", dan "tidal energy" juga memiliki korelasi yang berdekatan dalam klaster berwarna ungu.

Overlay visualization pada gambar 2 menunjukkan perubahan tren bahan kajian di bidang energi laut Indonesia dari tahun 2010 hingga 2018. "Tidal energy" di tahun 2010 menjadi topik riset yang sering dikaji oleh peneliti. Namun demikian, selama kurun 1 dekade terakhir terjadi perubahan topik bahan kajian riset dimana "wave energy" menjadi lebih dilirik sebagai bahan kajian di tahun 2014 dan "wave energy conversion" menjadi primadona bahan kajian di tahun 2018.

Density visualization pada gambar 3 menunjukkan kepadatan dari suatu bahan kajian. Secara default, density visualization pada VOSviewer ditunjukkan dengan perubahan warna dari biru ke hijau dan dari hijau ke kuning. Semakin banyak jumlah item yang muncul pada satu titik, maka semakin dekat warna titik tersebut kepada warna kuning. Pada gambar 3 dapat diketahui bahwa "wave energy" dan "wave energy conversion" adalah 2 bahan kajian dengan kepadatan yang sangat tinggi.

Selain menunjukkan klaster, perubahan tren, dan kepadatan bahan kajian, gambar 1-3 juga menunjukkan nama-nama lokasi yang berhubungan dengan daerah yang berpotensi memiliki sumber energi laut, baik arus pasang surut maupun gelombang laut. Diantara nama lokasi yang disebutkan adalah Aceh, Sunda Isles, West Nusa Tenggara, dan Bengkulu. Hal penting lain yang dapat disimpulkan melalui gambar 1-3 adalah bahwa kata kunci inti yang sering muncul pada topik penelitian energi laut Indonesia selalu berkaitan dengan (i) sumber daya energi laut (baik arus maupun gelombang), (ii) pemodelan, (iii) teknologi konversi energi laut, dan (iv) lokasi potensial untuk pengembangan energi laut.

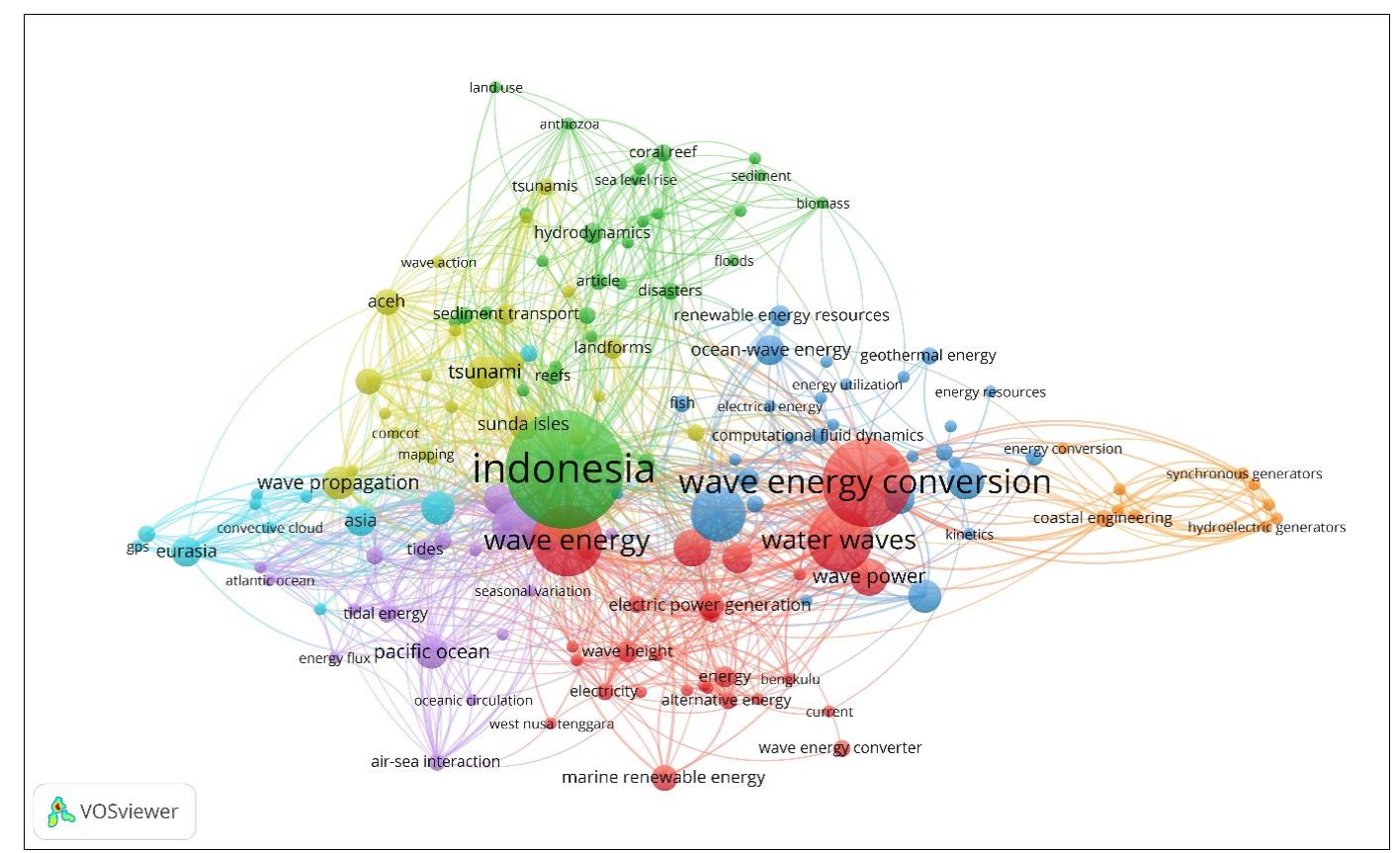

GAMBAR 1. Peta topik penelitian energi laut menggunakan network visualization. 


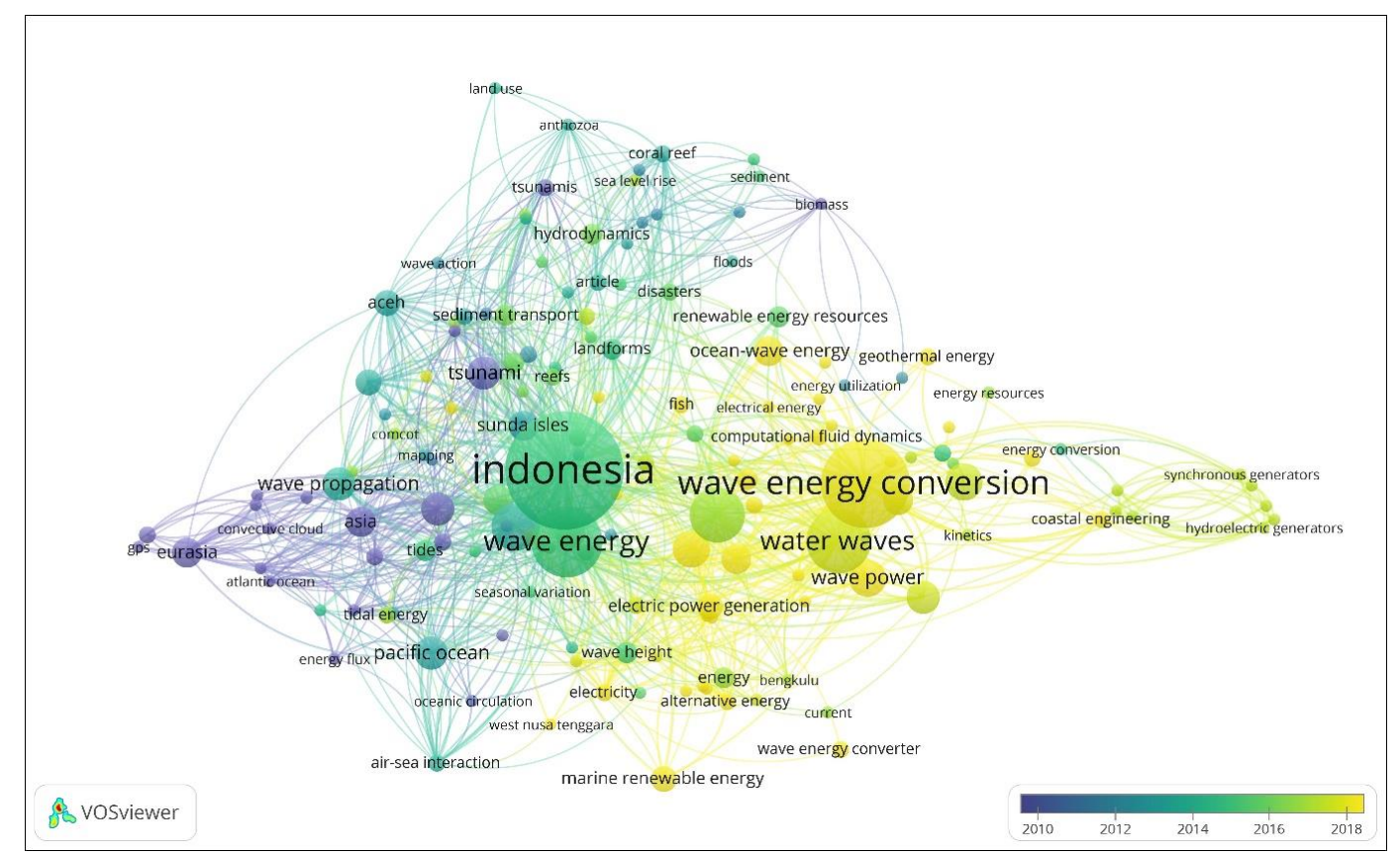

GAMBAR 2. Peta topik penelitian energi laut menggunakan overlay visualization.

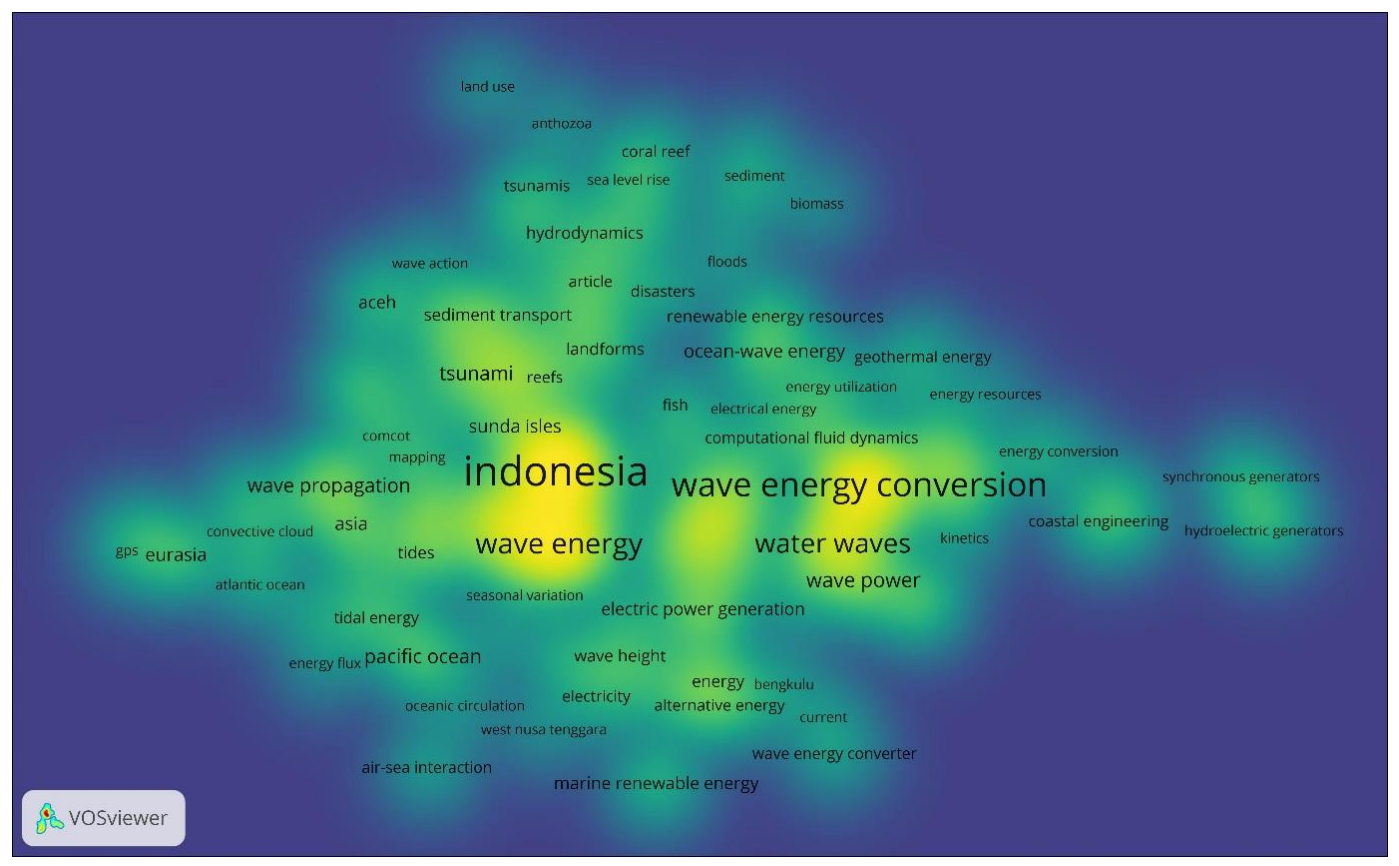

GAMBAR 3. Peta topik penelitian energi laut menggunakan density visualization.

\section{Visualisasi Peta Topik 2: Penelitian Biofouling dan Korosi di Perairan Laut}

Gambar 4, gambar 5, dan gambar 6 berikut masing-masing memvisualisasikan pemetaan bibliografik dengan topik biofouling dan korosi di perairan laut Indonesia menggunakan network visualization, overlay visualization, dan density visualization. Pada gambar 4 dapat diketahui bahwa biofouling berkaitan dengan ketahanan terumbu karang buatan ("artificial reef survival"), biodiversitas organisme laut dan lingkungan perairan laut ("marine environment"). Di sisi lain, korosi di perairan laut memiliki korelasi dengan "biocorrosion" dan "structural performance". Berdasarkan gambar 5, biofouling menjadi bahan penelitian yang paling banyak dikaji setelah 2015, kemudian tren bahan kajian beralih ke topik korosi dan biocorrosion menjelang 2020. Selain itu, gambar 4-6 juga 
menyebutkan beberapa jenis organisme laut yang menyebabkan terjadinya biofouling, diantaranya "mollusc", "porifera", dan "ascidia".

Berkaitan dengan dampak biofouling dan korosi di perairan laut, gambar 4-6 menyebutkan beberapa infrastruktur yang terdampak, diantaranya adalah "jetty", "bridge", dan "ship". Melalui analisis ini, dapat diketahui bahwa infrastruktur energi laut belum mendapat sorotan dalam bahan kajian biofouling dan korosi di perairan laut Indonesia hingga 2020. Sebaliknya, pada gambar 1-3 diketahui bahwa topik penelitian energi laut di Indonesia juga belum menyinggung tentang kajian biofouling dan korosi. Sehingga, dapat disimpulkan bahwa terdapat research gap pada 2 topik penelitian tersebut, dimana kajian yang membahas tentang dampak biofouling dan korosi pada infrastruktur energi laut di Indonesia masih belum banyak diteliti hingga saat ini.

A vosviewer

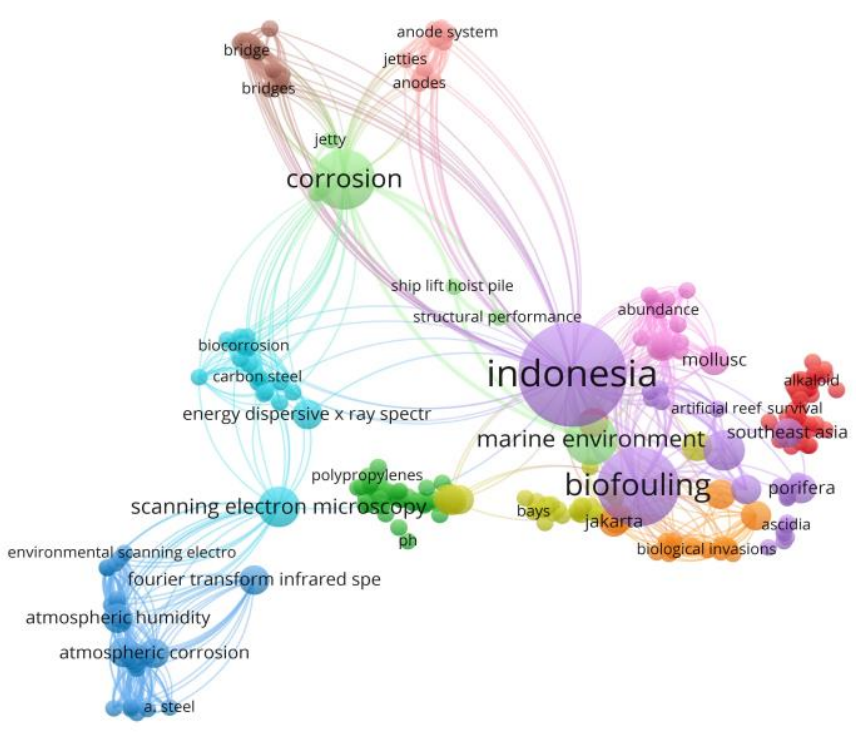

GAMBAR 4. Peta topik penelitian biofouling dan korosi di perairan laut menggunakan network visualization.

\section{Studi Kasus Biofouling Pada Infrastruktur Energi Laut di Negara Lain dan Potensi Penelitian di Indonesia}

Negara kepulauan Indonesia dengan sumber daya yang melimpah masih belum memanfaatkan potensi sumber daya energi terbarukan dari laut dengan optimal, mengingat hingga saat ini belum ada kapasitas pembangkit listrik energi laut yang terpasang di perairan tropis Indonesia. Beberapa penelitian yang telah dilakukan lebih banyak berfokus pada kajian potensi sumber daya (resources assessment) [12], pemodelan (modelling) [13, 14], dan peningkatan kinerja komponen pembangkit, seperti turbin [15], osilasi pendulum [16] dan mooring [17]. Hingga tahun 2016, Badan Pengkajian dan Penerapan Teknologi (BPPT) melalui Balai Teknologi Hidrodinamika telah mengembangkan prototipe teknologi arus laut generasi kelima sejak dikembangkan pertama kali di tahun 2008 [18]. Prototipe ini telah diuji di perairan Selat Flores dan Suramadu dengan kapasitas energy output berkisar 1,6 hingga 3,1 kW. Namun demikian, kajian ini juga belum meneliti secara spesifik dampak biofouling dan korosi terhadap kinerja perangkat pembangkit serta metode mitigasi dampaknya. Mengingat tahap perkembangan industri energi laut di Indonesia masih dalam fase research and development $(R n D)$ dan belum banyak ditemui kajian khusus tentang dampak biofouling dan korosi di perairan tropis Indonesia terhadap infrastruktur energi, maka diperlukan pembelajaran dari studi kasus di negara lain. 


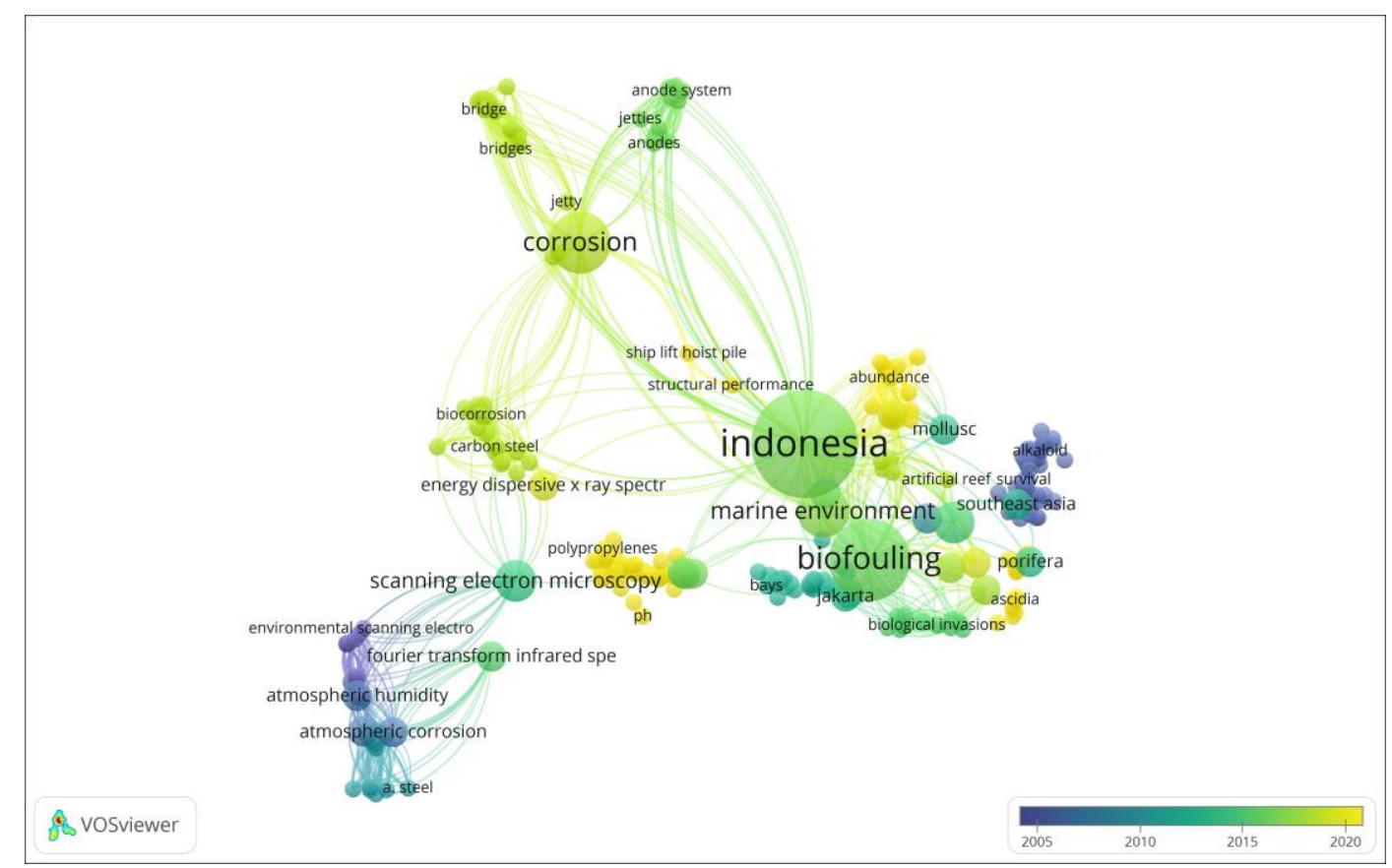

GAMBAR 5. Peta topik penelitian biofouling dan korosi di perairan laut menggunakan overlay visualization.

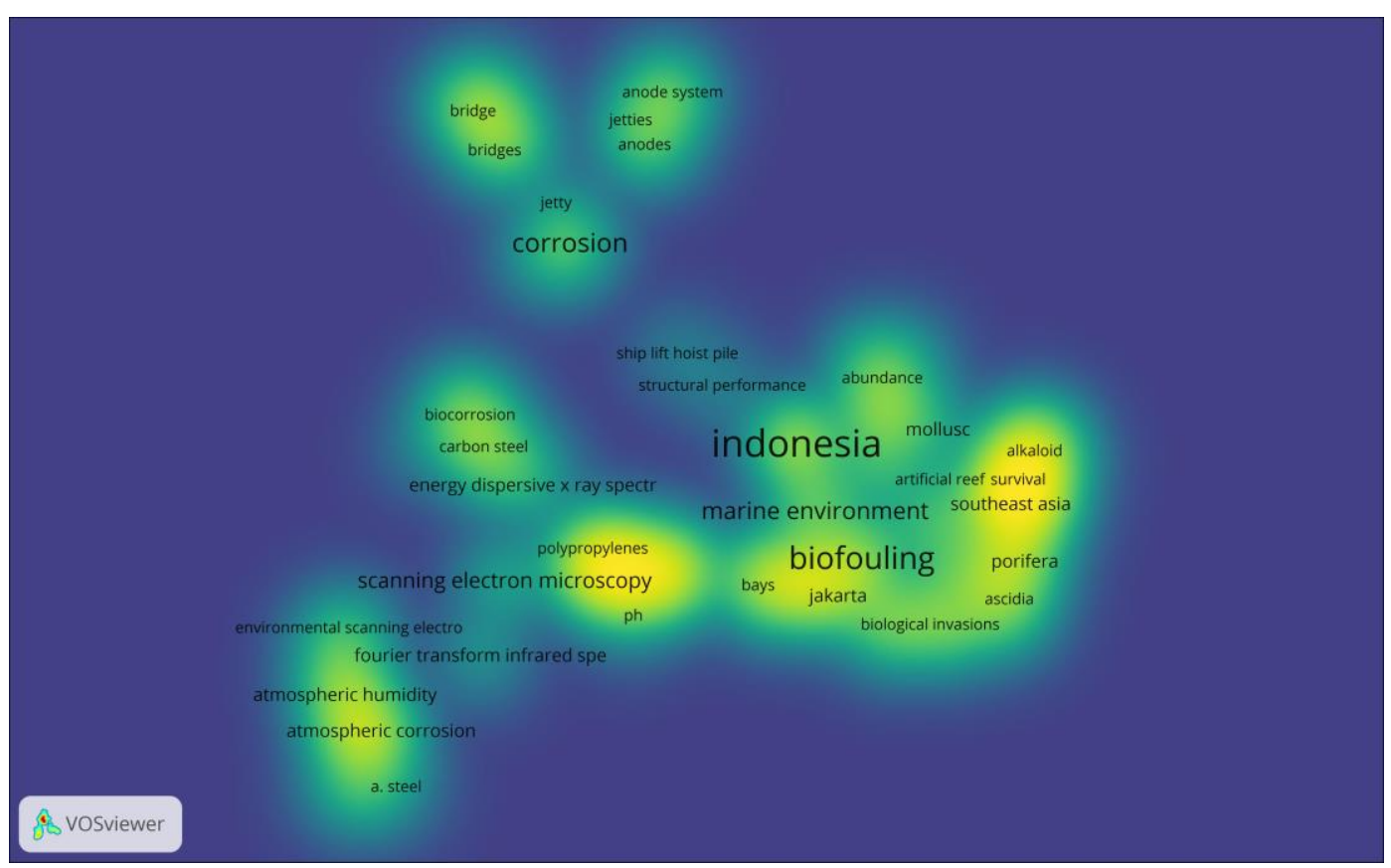

GAMBAR 6. Peta topik penelitian biofouling dan korosi di perairan laut menggunakan density visualization.

Beberapa peneliti telah melakukan kajian dampak biofouling dan korosi pada infrastruktur energi laut dan offshore wind di perairan beriklim sedang (temperate waters) [7-9, 19]. Kajian yang terbaru di perairan beriklim sedang Eropa telah menghimpun database tentang organisme-organisme laut yang paling dominan menyebabkan terjadinya biofouling pada perangkat pembangkit energi laut [19]. Studi mutakhir ini juga membahas tentang dampak masing-masing organisme yang ditimbulkan pada kinerja perangkat pembangkit, diantaranya bertambahnya kekasaran dan ketebalan permukaan, serta berat perangkat yang menyebabkan terjadinya drag. Selain itu, dampak yang lain adalah beberapa jenis organisme laut memiliki tingkat adhesi yang tinggi terhadap 
permukaan perangkat pembangkit, sehingga dapat menyebabkan resiko yang lebih buruk dengan terjadinya korosi (microbially influenced corrosion) [9, 19].

Beberapa faktor utama yang mempengaruhi terjadinya fenomena biofouling adalah (i) jenis material yang digunakan sebagai komponen, (ii) suhu air laut, (iii) arus dan jarak penempatan alat dari pantai, dan (iv) kedalaman penempatan perangkat di bawah permukaan laut yang berkorelasi terhadap tingkat ketersediaan cahaya matahari [19]. Berkaitan dengan pengaruh kedalaman alat terhadap potensi biofouling, kajian investigasi telah dilakukan menggunakan prototipe teknologi "Pelamis", salah satu teknologi pembangkit energi gelombang laut yang diuji di Billia Croo, Orkney, UK [20]. Kajian ini mendapati bahwa beberapa jenis komunitas biofouling yang berbeda menempel pada perangkat "Pelamis" dengan kedalaman laut yang berbeda. Pada daerah subtidal dengan kedalaman hingga $0,25 \mathrm{~m}$, beberapa jenis alga didapati mendominasi daerah penumpukan biofouling. Di sisi lain, beberapa jenis organisme invertebrata mendominasi penumpukan biofouling pada perangkat dengan kedalaman 0,5 hingga $2 \mathrm{~m}$. Kajian ini menegaskan bahwa spesies penyebab terjadinya biofouling bervariasi terhadap lokasi kedalaman perangkat di dalam laut yang berhubungan dengan tingkat ketersediaan cahaya matahari [20].

Melalui analisis bibliometrik atas topik penelitian energi laut di Indonesia dan kajian biofouling dan korosi di perairan laut Indonesia, diketahui bahwa masih terdapat research gap dari beberapa penelitian yang telah dilaksanakan selama 2 dekade terakhir. Namun demikian, mengingat perkembangan industri energi laut Indonesia masih pada fase awal, research gap tersebut dapat dijadikan sebagai topik penelitian yang potensial untuk dikaji dalam waktu dekat. Beberapa penelitian sejenis yang telah dilakukan di negara Eropa dapat dijadikan sebagai bahan rujukan untuk menyusun roadmap penelitian biofouling dan korosi pada infrastruktur energi laut Indonesia.

Perlu diingat bahwa negara-negara Eropa berada di wilayah perairan beriklim sedang (temperate waters), yang memiliki karakteristik lingkungan laut yang berbeda dengan perairan tropis (tropical waters) di Indonesia. Sehingga, faktor lingkungan perairan tropis yang dapat mempengaruhi terjadinya biofouling dan korosi juga perlu untuk dikaji. Berdasarkan hasil analisis bibliometrik dan review diatas, diperlukan studi yang komprehensif untuk mengkaji topik penelitian biofouling dan korosi dengan melibatkan beberapa disiplin ilmu yang berbeda, diantaranya meliputi bidang: Teknik Material, Teknik/Ilmu Lingkungan, Biologi, Energi Terbarukan dan Statistik.

\section{KESIMPULAN}

Perkembangan industri energi laut Indonesia hingga saat ini masih dalam tahap penelitian yang lebih banyak berfokus pada kajian sumber daya energi (resources assessment), peningkatan kinerja komponen dan uji prototipe di lapangan (field trial). Aspek teknis yang berkaitan dengan ketahanan material pada perangkat terhadap lingkungan perairan laut terutama yang berkorelasi dengan biofouling dan korosi masih belum banyak dikaji secara mendalam. Di sisi lain, perkembangan penelitian biofouling dan korosi di perairan tropis Indonesia juga belum banyak menyentuh infrastruktur energi laut sebagai objek kajian. Melalui analisis bibliometrik dalam studi ini, ditemukan bahwa kajian dampak biofouling dan korosi pada infrastruktur energi laut adalah topik penelitian yang memiliki kebaruan untuk dapat dikaji secara komprehensif dalam waktu dekat. Kajian biofouling dan korosi di perairan tropis Indonesia dapat merujuk pada kajian-kajian sejenis yang telah dilakukan di wilayah perairan beriklim sedang (temperate waters). 


\section{DAFTAR PUSTAKA}

[1] Government Regulation No. 79 of 2014, National Energy Policy (KEN) T. G. o. R. o. Indonesia, 2014.

[2] I. P. o. C. Change, "Mitigation of Climate Change - Working Group III Contribution to the Fifth Assessment Report of the Intergovernmental Panel on Climate Change," Cambridge University Press, 2014.

[3] M. o. E. a. M. R. I. a. I. O. E. Association, "Ocean Energy Resources in Indonesia. Technical Note," 2014.

[4] K. M. ESDM, "Pengesahan Rencana Usaha Penyediaan Tenaga Listik Pt Perusahaan Listrik Negara (Persero) Tahun 2019 Sampai Dengan Tahun 2028," 2019.

[5] C. Trust, Best Practice Innovation Policy for Emerging Renewable Energy Technologies, Summary Presentation, 2014.

[6] F. L.-F. Erik G. Hansen, Xiaohong (Iris) Quan, Joel West, "Beyond Technology Push vs. Demand Pull: The Evolution of Solar Policy in the U.S., Germany and China."

[7] A. K. Macleod, M. S. Stanley, J. G. Day, and E. J. Cook, "Biofouling community composition across a range of environmental conditions and geographical locations suitable for floating marine renewable energy generation," Biofouling, vol. 32, no. 3, pp. 261-276, 2016.

[8] A. Want, R. Crawford, J. Kakkonen, G. Kiddie, S. Miller, R. E. Harris, and J. S. Porter, "Biodiversity characterisation and hydrodynamic consequences of marine fouling communities on marine renewable energy infrastructure in the Orkney Islands Archipelago, Scotland, UK," Biofouling, vol. 33, no. 7, pp. 567-579, 2017.

[9] S. Price, and R. Figueira, "Corrosion Protection Systems and Fatigue Corrosion in Offshore Wind Structures: Current Status and Future Perspectives," Coatings (Basel), vol. 7, no. 2, pp. 25, 2017.

[10] D. Féron, R. Basséguy, T. Liengen, and I. B. Beech, "Biofilms and Biocorrosion," Elsevier, 2014, pp. 1-1.

[11] T. R. Bott, "Industrial biofouling: occurrence and control," Elsevier, 2011.

[12] A. Wahyudie, T. B. Susilo, F. Alaryani, C. S. A. Nandar, M. A. Jama, A. Daher, and H. Shareef, "Wave Power Assessment in the Middle Part of the Southern Coast of Java Island," Energies (Basel), vol. 13, no. 10, pp. 2633, 2020.

[13] K. Orhan, R. Mayerle, and W. W. Pandoe, "Assesment of Energy Production Potential from Tidal Stream Currents in Indonesia," Energy Procedia, vol. 76, pp. 7-16, 2015.

[14] K. Orhan, and R. Mayerle, "Assessment of the tidal stream power potential and impacts of tidal current turbines in the Strait of Larantuka, Indonesia," Energy Procedia, vol. 125, pp. 230-239, 2017.

[15] Erwandi, D. Rahuna, and C. S. J. Mintarso, "The development of the IHL wavecurrent turbine to convert the ocean energy from both wave and current," IOP conference series. Materials Science and Engineering, vol. 588, pp. 12008, 2019.

[16] I. S. Arif, I. K. A. P. Utama, R. Hartono, J. Prananda, R. Isnaini, and T. Rachmattra A, "Analysis Characteristics Of Pendulum Oscillation In PLTGL-SB," E3S web of conferences, vol. 43, pp. 1005, 2018.

[17] I. S. Arief, I. K. A. P. Utama, R. Hantoro, J. Prananda, T. R. Arvisa, and R. F. Kusuma, "Mooring Experimental Study of Motion Response for Pendulum Wave Energy Converters," IOP conference series. Materials Science and Engineering, vol. 462, pp. 12010, 2019.

[18] A. Kasharjanto, D. Rahuna, and R. Rina, "Kajian Pemanfaatan Energi Arus Laut Di Indonesia," Wave: Jurnal Ilmiah Teknologi Maritim, vol. 11, no. 2, pp. 75-84, 2017. 
[19] P. A. Vinagre, T. Simas, E. Cruz, E. Pinori, and J. Svenson, "Marine Biofouling: A European Database for the Marine Renewable Energy Sector," Journal of marine science and engineering, vol. 8, no. 7, pp. 495, 2020.

[20] C. R. Nall, M.-L. Schläppy, and A. J. Guerin, "Characterisation of the biofouling community on a floating wave energy device," Biofouling (Chur, Switzerland), vol. 33, no. 5, pp. 379-396, 2017. 